\title{
KAJIAN TENTANG PERATURAN DAERAH (PERDA) BERNUANSA AGAMA DAN MASA DEPAN HARMONISASI UMAT BERAGAMA DI INDONESIA
}

\author{
I Gusti Ngurah Oka
}

\begin{abstract}
PENDAHULUAN
Keputusan politik pemerintah Indonesia dalam memberlakukan Otonomi Daerah (Otda) yang dimulai sejak tahun 2001 telah memungkinkan lahirnya produk-produk hukum lokal dengan nuansa syariah Islam. Sebagian kalangan mengkhawatirkan munculnya Peraturan Daerah, seperti tentang kewajiban mengenakan busana Muslim atau kewajiban membaca Al-Qur'an, berpotensi membunuh keberagaman dan bersifat diskriminatif. Namun beberapa penguasa daerah mengaku Perdaperda itu mampu menekan angka kejahatan dan meningkatkan moralitas

Keinginan tersebut semakin kuat ketika secara yuridis formal melalui undang-undang nomor 44 tahun 1999 dan undang-undang nomor 18 tahun 2001, pemerintah memperkenankan pelaksanaan syari'at Islam di Propinsi Nanggroe Aceh Darussalam (NAD). Sikap ini kemudian dibalas dengan Raperda berdasarkan Injil di Kabupaten Manokwari, Papua Barat. Di antara pasal-pasal yang kontroversial adalah Pasal 26 yang mengatur bahwa "pemerintah dapat memasang simbol agama di tempat umum dan perkantoran." Pasal 30 melarang "pembangunan rumah ibadah agama lain jika sudah ada Gereja." Juga larangan penggunaan jilbab dan mengumandangkan azan keras-keras.
\end{abstract}

\section{POKOK PERMASALAHAN}

Perda-perda bernuansa agama secara de facto telah diberlakukan di 58 kabupaten/kota. Jika isi dari Perda-perda tersebut kita cermati, maka dapat memunculkan benih-benih perpecahan bangsa yang menjadi ancaman bagi keutuhan Negara Kesatuan Republik Indonesia (NKRI). Pendekatan Perda-perda tersebut lebih bernuansa sektarian, tidak mengedepankan pendekatan kebangsaan. Selain itu setiap Perda yang dibuat harus sesuai dengan undang-undang di atasnya, yaitu harus bersifat Bhineka Tunggal Ika, tidak memisah-misahkan agama, suku, ras, dan gender. Di samping itu 
beberapa kebijakan yang tidak bisa diatur oleh peraturan daerah, mengenai keamanan, tentang fiskal atau keuangan, tentang pelabuhan, dan tentang agama yang merupakan wewenang pemerintah pusat. Namun Perda-perda itu justru mengatur hal-hal tersebut, misalnya soal agama.

Perda syariat menimbulkan pro dan kontra di kalangan masyarakat luas, para alim ulama, dan para pejabat pemerintah (eksekutif, legislatif, yudikatif). Perda ini menimbulkan keresahan dan kegelisahan di kalangan masyarakat luas, khususnya pada kelompok masyarakat minoritas dan kelompok yang rentan terhadap dampak dari penerapan Perda tersebut seperti golongan masyarakat miskin. Adanya golongan pro-kontra mengindikasikan penyusunan Perda syariat belum melibatkan publik seluas-luasnya. Sebagian orang menilai para pembuat Perda cenderung bersikap arogan dan elitis (tertutup).

Pemerintah daerah semestinya berfungsi sebagai fasilitator dalam pelayanan publik sehingga kepentingan publik harus lebih diutamakan. Pemda dan DPRD dalam membuat Perda seharusnya mendengarkan sebanyak mungkin aspirasi dan pendapat serta keinginan masyarakat. Dengan melibatkan partisipasi publik ini, Perda-perda yang disusun ketika disahkan tidak mengundang reaksi atau penolakan dari elemen masyarakat. Di sini diperlukan kepekaan dalam mengakomodir aspirasi rakyat, sehingga pada saat Perda diberlakukan tidak mendapat reaksi yang tajam dari masyarakat. Beberapa pokok permasalahan Perda syariat yang diterapkan di berbagai daerah, di antaranya sebagai berikut.

\section{Segi Tertib Hukum di Indonesia}

Perda syariat tidak sesuai dengan UU No. 10/2004 tentang Pembentukan Peraturan Perundang-undangan. Karena dari segi penjaringan aspirasi tidak utuh. Proses penjaringan mengandung "manipulasi" karena mendatangkan orang luar untuk membawa aspirasi yang kemudian diklaim sebagai aspirasi masyarakat. UU No. 10 secara jelas menyebutkan hirarki peraturan berdasar UU itu. Perda jelas ada di bawah UU No.32/2004, yang mengatakan bahwa masalah keagamaan adalah masalah pusat. Jika masalah keagamaan diatur dalam Perda, berarti bisa diintepretasikan kewenangan pusat diambil alih oleh daerah.

\section{Segi Legal Drafting}

Perda ini bersumber dari hukum Islam. Karena tidak ada dalam Undang-Undang Dasar (UUD) atau Undang-undang (UU) yang 
menyebutkan Al-Quran dan Hadits menjadi pertimbangan Perda. Dengan demikian Perda melecehkan Al-Quran dan Hadits, karena sesungguhnya Perda ada di hirarki peraturan paling bawah menurut UU No. 10/2004. Apalagi, Perda sejenis hanya menyalin dari daerah lain dan hanya diganti judulnya.

\section{$\underline{\text { Segi Moral-Politis }}$}

Pembuatan Perda syariat terkesan hanya untuk menarik simpati masyarakat menjelang pilkada. Karena dari segi substansi, jelas tidak signifikan di dalam masyarakat Indonesia yang kenyataannya beragam, tidak prioritas dan sangat prosedural. Seperti Propinsi Kalimantan Selatan yang membuat Perda Jumat Khusu', Raperda Larangan Mandi di Sungai dan Perda Ramadhan, lain halnya jika Perda ditujukan untuk memberantas korupsi pejabat yang tentu lebih bernuansa syariat, menyeluruh dan mendesak.

\section{$\underline{\text { Segi Stabilitas Keamanan }}$}

Perda syariat jika tidak disosialisasikan secara transparan dapat memperuncing perbedaan pandangan atau persepsi masyarakat, khususnya pada kelompok pro-kontra serta menimbulkan kecurigaan di antara dua kelompok tersebut dengan berbagai tuduhan motif yang melatarbelakangi.

\section{$\underline{\text { Segi Rasa Keadilan Masyarakat }}$}

Perda syariat bila dalam implementasinya tidak mengakomodir suara-suara dari kelompok yang merasa dirugikan atau mencari solusi secara komprehensif, maka dikhawatirkan dapat menimbulkan dampak negatif dan merugikan kehidupan dan penghidupan kelompok-kelompok tertentu, seperti: kaum perempuan, para pelajar, pegawai atau karyawan, serta kelompok-kelompok yang rentan secara ekonomis.

\section{PENGERTIAN PERDA BERNUANSA AGAMA}

Secara umum Perda bernuansa agama dapat dipahami dalam beberapa pengertian sebagai berikut. 
Pertama, peraturan daerah yang diberlakukan khusus untuk agama tertentu saja, misalnya untuk umat Islam, Kristen, Hindu, Buddha, atau Kong $\mathrm{Hu} \mathrm{Chu}$.

Kedua, peraturan daerah yang bersifat eksklusif yang merupakan peraturan yang cenderung kepada aturan salah satu agama saja.

Ketiga, segala Perda yang berkaitan dengan ajaran agama. Misalkan agama Islam melarang pelacuran maka segala Perda yang melarang pelacuran adalah Perda syariat. Karena agama Kristen mengajarkan monogami tulen, maka setiap Perda yang menyuruh pegawai negeri untuk hanya mempunyai satu istri saja adalah Perda bernuansa syariat Kristen.

Keempat, segala Peraturan Daerah yang disepakati antar ulama (Islam) dan umara dengan DPRD setempat yang menjurus kepada mayoritas, bukan partai.

Kelima, segala Peraturan Daerah yang diajukan oleh partai berasaskan Pancasila (seperti Golkar) tetapi mayoritasnya muslim

Dari beberapa pengertian di atas, dapat disimpulkan bahwa Perda bernuansa agama adalah Peraturan Daerah yang isinya cenderung memberlakukan aturan-aturan yang berasal dari ajaran salah satu agama tertentu.

\section{PERDA BENUANSA AGAMA DITINJAU DARI PERSPEKTIF HUKUM NASIONAL}

Ratifikasi Perda bernuansa agama di sejumlah daerah menjadi sorotan publik karena tidak menyentuh masalah yang substansial, tapi lebih bersifat simbolistik. Perda ini dianggap bertentangan dengan sistem Hukum Nasional. Dalam Kitab Undang-undang Hukum Pidana (KUHP), sudah diatur peraturan mengenai pelacuran, minuman keras dan perjudian, sehingga Perda bernuansa agama dipandang hanya pengulangan yang tidak perlu dari KUHP.

Di tingkat nasional, argumen yang sering dikemukakan para pembela syariat adalah bahwa hukum nasional kita merupakan warisan penjajah sehingga perlu diganti dengan hukum yang lebih berakar pada nilai-nilai Islami. Tidak dipungkiri bahwa KUHP kita adalah warisan kolonial Belanda, dan banyak titik lemah dalam hukum nasional kita, termasuk KUHP-nya. Maka sejak tahun 1980-an dibentuk badan untuk melakukan revisi KUHP tersebut. Namun peraturan undang-undang yang berlaku adalah selama hukum yang baru belum jadi dan belum diberlakukan, maka peraturan yang lama tetap berlaku secara sah. 
Perlu dipahami bahwa konstitusi, hukum nasional, maupun Perda tidak boleh didasarkan pada nilai-nilai komunal yang tunggal. Hukum seharusnya dibangun di atas semua sendi kemajemukan bangsa yang mengedepankan nilai keadilan sosial. Jika proses lahirnya Perda syariat sesuai dengan koridor dan prosedural demokrasi di Indonesia karena diputuskan oleh Lembaga Perwakilan Rakyat, namun dalam UUD' 45 bahkan setelah diamandemen, telah menegaskan bahwa Pembukaan UUD' 45, di mana Pancasila termaktub di dalamnya tidak akan dirubah. Artinya, seharusnya proses demokrasi yang berlangsung di tingkat DPRD harus juga taat dengan asas dan konstitusi Indonesia. Tetapi, dalam konteks kelahiran Perda syariat, nampaknya hal ini diabaikan. Adalah tugas negara untuk meluruskan kekeliruan ini, sesuai dengan amandemen UUD' 45 pasal 24a, soal MA melakukan judicial review terhadap perundangan di bawah UU. Atau, juga sesuai UU No 32/2004 mengenai pemerintah daerah, pasal 145, Departemen Dalam Negeri juga punya kewenangan menguji Perda (executive review). Bunyi pasal itu adalah: "Pemerintah (DEPDAGRI) dapat membatalkan Perda yang bertentangan dengan kepentingan umum dan peraturan perundangan yang lebih tinggi."

Nampaknya, kehadiran Perda syariat, pada satu sisi merefleksikan kegagalan pemerintah dalam mengimplementasi hukum di Indonesia. Kegagalan ini berdampak pada sisi lain, di mana kemudian banyak orang merasa berhak untuk membuat atau mencari aturan alternatif karena menunjuk ketidakmampuan hukum dalam mengatasi banyak persoalan. Meskipun sebenarnya, kegagalan lebih pada aparat pelaksananya, bukannya pada hukum itu sendiri. Karena itu, Perda syariat lebih banyak merefleksikan kegagalan negara dalam penegakkan hukum.

\section{MAYORITAS MASYARAKAT INDONESIA MASIH MENGIDEALKAN PANCASILA}

Mayoritas masyarakat Indonesia lebih memilih penerapan hukum nasional dibandingkan aturan hukum yang mengacu pada suatu ajaran agama tertentu. Sebagai contoh, mayoritas masyarakat Islam sendiri lebih memilih penerapan hukum nasional dibanding aturan hukum lain, seperti peraturan daerah (Perda) bernuansa syariat Islam. ${ }^{1}$ Contohnya survei yang

${ }^{1}$ Paparan 'Respon Publik Atas Perda Bernuansa Syariat Islam' di Jakarta, oleh Direktur Eksekutif Lingkaran Survei Indonesia (LSI) Denny JA. 
dilakukan oleh LSI (Lembaga Survei Indonesia) ${ }^{2}$ di 33 provinsi pada tanggal 28 Juli s.d. 3 Agustus 2006, mencatat 66,7\% responden lebih mengidealkan Pancasila daripada sistem ideologi ketatanegaraan lain (Demokrasi Barat atau Negara Islam Timur Tengah). Pasalnya, Pancasila terbukti berhasil menjadi ideologi di tengah keberagaman yang ada, baik dari sisi adat, agama, suku, dan sebagainya. Dalam paparannya, dari 700 orang sebagai sampel survei, $64,3 \%$ responden menyatakan hukum nasional sebaiknya tetap diterapkan di Indonesia karena menjamin adanya keberagaman. Hal ini diperkuat oleh temuan di mana responden yang beragama Islam sendiri $(61,7 \%)$ lebih memilih hukum nasional.

Mayoritas muslim Indonesia sejak lama lebih berorientasi pada keberagaman dan kebangsaan. Dalam tiga kali pemilu bebas $(1955,1999$, 2004), partai yang menang adalah yang berbasis kebangsaan. Apalagi dua ormas Islam besar, Muhammadiyah dan Nahdlatul Ulama (NU), sejak awal telah menyatakan Pancasila sebagai dasar Negara. Mayoritas responden sebanyak 61,4\% menyatakan kekhawatirannya bahwa Perda yang bernuansa syariat agama dapat mendorong perpecahan. Dan terdapat 59,7\% responden yang beragama Islam juga menyatakan kekhawatiran yang sama. Hasil survei ini memperkuat dugaan bahwa mayoritas muslim Indonesia memang moderat, berbeda dengan mayoritas muslim di Timur Tengah. Negara ini selalu dipimpin oleh presiden yang memiliki komitmen yang kuat dengan keberagaman, yang disimbolkan oleh Pancasila.

Mayoritas Muslim Indonesia lebih memilih bersikap moderat lebih disebabkan oleh penetrasi panjang dan masif atas asas tunggal Pancasila di masa orde baru. Selain itu, pemihakan oleh Muhamadiyah dan Nahdlatul Ulama (NU) berpihak pada Pancasila. Tokoh intelektual Islam seperti Abdurrachman Wahid (alm.) dan Nurcholis Madjid (alm.) yang moderat juga mendukungnya.

Responden lebih memilih penegakkan hukum yang ada dibanding membuat Perda berdasarkan syariat Islam. Aturan hukum yang diatur oleh KUHP juga sudah mengatur soal anti kemaksiatan. 61,4\% responden justru sangat khawatir jika Perda bernuansa syariat diberlakukan.

\section{ARGUMEN PRO - KONTRA TERHADAP PERDA SYARIAH}

\footnotetext{
${ }^{2}$ Suara Merdeka Cybernews, 24 Agustus 2006 dengan topik : Masyarakat pilih hukum Nasional.
} 
Bagi pihak yang menolak diberlakukannya Perda syariah memiliki sejumlah argumentasi berikut.

\section{Perda Syariah Dapat Menggeser Ideologi Pancasila}

Perda-perda bernuansa agama dianggap sebagai bentuk gerilya lain dari kelompok Islam fundamental yang ingin menegakkan syariat Islam di Indonesia. Setelah gagal mengubah Dasar Negara dari Pancasila versi Pembukaan UUD tanggal 18 Agustus 1945 ke Pancasila versi Piagam Jakarta, kalangan gerakan Islam Politik berjuang membuat Perda-perda syariat.

\section{Mengancam Integrasi Bangsa}

Peraturan Daerah bernuansa primordial keagamaan dapat mengancam pluralitas masyarakat Indonesia, meresahkan dan dapat mengancam integrasi bangsa.

\section{Bertentangan Dengan Konstitusi Negara}

Meskipun mayoritas penduduk Indonesia beragama Islam, namun bangunan hukum di Indonesia adalah negara Pancasila. Jika Perda syariat diterapkan akan bertentangan dengan konstitusi negara. Karena dalam negara Pancasila tidak bisa memuat ketentuan atau menjadikan hukum agama menjadi hukum negara yang diangkat melalui Perda. ${ }^{3}$

\section{Tidak Bisa Menjawab Persoalan Substansi Bangsa}

Ada realitas sosial di balik pemberlakukan Perda syariat Islam di berbagai daerah. Ternyata Perda syariat tidak dapat menjawab berbagai persoalan substansial bangsa tentang kemiskinan, kerusakan lingkungan, dan korupsi yang merajalela. Hal ini disebabkan karena Perda tersebut cenderung menghukum para pelaku kejahatan kelas teri (orang-orang kecil) seperti perjudian, pencurian, dan perzinahan. Perda syariat tidak punya taring menghadapi pelaku korupsi kelas kakap, pembalak hutan, penjahat HAM yang justru memiliki kedekatan politik dengan para tokoh organisasi

${ }^{3}$ Pendapat Direktur Eksekutif Pusat Studi Hukum dan Kebijakan (PSHK) Indonesia Bivitri Susanti dan Staf Ahli Mahkamah Konstitusi (MK) Refly Harun. 
pendukung Perda syariat. Pemberlakuan syariat Islam di Aceh, misalnya, hanya mampu menghukum pencuri, penjudi dan penzinah kelas kecil.

\section{Kebenaran Moral Dipegang Hanya Oleh Kelompok Tertentu}

Perda syariat juga memiliki dimensi pembalikan terhadap nilai moralitas yang hakiki, karena menyerahkan kebenaran moral kepada para pemegang tafsir kebenaran agama yang dimiliki oleh para ulama yang dekat dengan kekuasaan.

\section{Masyarakat Mengalami Tekanan Politik}

Perda syariat secara realitas, seperti tampak dan dirasakan masyarakat Aceh, hanya melahirkan ketertekanan politik kepada masyarakat bawah yang seolah-olah diatur dengan moralitas abstrak. Sementara para pejabat dan ulama menjadi pemegang kebenaran moral syariat agama.

\section{Tidak Memberdayakan Masyarakat}

Perda syariat boleh jadi bisa menurunkan angka kejahatan dan penyakit masyarakat, namun tidak menurunkan kejahatan politik para elite politik dan birokrasi. Justru dari pengalaman negara-negara yang mempraktikkan syariat Islam secara ortodoks, tingkat ekonomi, kesetaraan hak rakyat, dan prestasi IPTEK-nya sangat rendah. Afghanistan, Somalia, dan Sudan barangkali bisa menjadi bukti keterpurukan negara yang menjalankan syariat Islam. Bisa dibandingkan dengan China, Vietnam, Bolivia, dan Libia yang menjalankan sistem sosialis dan sosialis-Islam ternyata lebih maju dan berkembang. Demikian juga Malaysia yang menjalankan asas Islam yang moderat pertumbuhan ekonominya jauh lebih maju.

\section{Bertentangan Dengan Birokrasi Modern}

Perda berbasis syariat tidak memiliki paradigma birokrasi modern. Birokrasi pemerintahan yang modern seharusnya lebih berfungsi sebagai katalis yang tidak perlu mengatur bidang-bidang yang seharusnya dapat dikerjakan sendiri oleh masyarakat. Birokrasi seharusnya memberdayakan masyarakat agar tidak tergantung sepenuhnya kepada pemerintah, bukan sebaliknya mempersulit masyarakat dengan atural detail. 
Sementara pihak lain yang setuju adanya Perda Syariah beragumentasi sebagai berikut.

\section{Perda Syariah Bukanlah Gerakan Islamisasi}

Telah banyak undang-undang yang diambil dari hukum Islam, misalnya: undang-undang perkawinan, undang-undang mengenai zakat, undang-undang tentang bank syariah, dan sebagainya. Namun demikian tidak bisa dikatakan telah terjadi Islamisasi di Indonesia.

\section{Mencegah kerusakan moral dalam masyarakat}

Masyarakat seharusnya tidak perlu mengkhawatirkan akan terjadinya desintegrasi bangsa, karena Rancangan Undang-Undang Anti Pelacuran dan Perjudian (RUU APP) telah mengakomodasi seni tradisional dan budaya daerah. RUU APP justru diperlukan untuk melindungi bangsa ini, terutama generasi muda, dari berbagai kerusakan moral akibat pengaruh pornografi dan pornoaksi yang kini merebak di mana-mana. Adanya Perda tersebut bisa menjadi media sosial untuk memberantas berbagai penyakit masyarakat seperti kemaksiatan, perjudian, yang umumnya dilakukan oleh masyarakat kecil.

\section{Agama Lain Juga Melawan Hal yang Sama}

Materi yang diatur mengenai minuman keras, kemaksiatan dan pelacuran yang coba diatasi melalui Perda syariat juga adalah sesuatu yang sama harus dilawan oleh agama-agama non-Muslim lainnya.

\section{Kelahirannya Prosedural dan Demokratis}

Proses dilahirkannya Perda syariat berlangsung secara prosedural dan demokratis, dan bersesuaian dengan mekanisme kerja DPRD Kabupaten dan kota. 
Missio Ecclesiae, 3(1), April 2014, 86-103

\section{PENDEKATAN SOSIOLOGIS HARMONISASI UMAT BERAGAMA}

Pendekatan sosiologis diperlukan dalam upaya menciptakan harmonisasi antar umat beragama di Indonesia. Beberapa pendekatan sosiologis yang dapat dilakukan seperti di bawah ini.

\section{Tri-Kerukunan Umat Beragama}

Frasa "kerukunan hidup" bagi umat beragama mencakup hubungan dengan Tuhan, hubungan dengan diri sendiri, hubungan dengan sesama manusia dan hubungan dengan lingkungan alam sekitar. Secara garis besar terdapat dua macam hubungan sosial keagamaan yaitu hubungan intern umat beragama dan hubungan antar umat beragama. Perilaku menyangkut hubungan dengan Tuhan, hubungan dengan diri sendiri serta hubungan dengan alam sekitar dinamakan sebagai "hubungan non-sosial." Bagi umat beragama yang sungguh-sungguh dalam keberagamannya, seluruh hubungan dimaksud bersifat utuh terpadu (integrated), mengacu kepada ajaran agama yang dianut.

Konsep Tri-Kerukunan umat beragama pernah dirumuskan dan ditetapkan pada masa pemerintahan Orde Baru dengan melibatkan semua tokoh agama. Keberhasilan Orde baru dalam menciptakan kerukunan umat beragama tidak bisa dilepaskan dari kebijakan politis penguasa saat itu, yakni terciptanya stabilitas Nasional demi berlangsungnya proses pembangunan nasional yang lebih menekankan pendekatan keamanan (security approach). Orde baru mengembangkan konsep Tri-Kerukunan yang mencakup Kerukunan intern umat beragama, Kerukunan antar umat beragama, dan Kerukunan antar umat beragama dengan Pemerintah. Apabila dicermati lebih dalam konsep "Kerukunan antara umat beragama dengan Pemerintah" mengandung penyimpangan logis, sebab Pemerintah mengandung konsep yang tumpang tindih dengan "umat beragama." Penerapan konsep ini pada masa yang lalu juga bermasalah, karena memposisikan Pemerintah sebagai "pembina" umat beragama, dan umat beragama sebagai "yang dibina." Maka terjadilah pola pembinaan kerukunan hidup umat beragama yang bersifat top-down (dari atas ke bawah), yang hasilnya kurang mencapai harapan.

Penjelasan tentang ruang lingkup di atas adalah sesuai dengan definisi yang dikemukakan oleh Departemen Agama RI sebagai berikut: "Kerukunan hidup Umat Beragama, berarti perihal hidup rukun yaitu hidup dalam suasana baik dan damai, tidak bertengkar; bersatu hati dan 
bersepakat antar umat yang berbeda-beda agamanya; atau antara umat dalam satu agama." Namun agar terhindar dari masalah "pencampuran agama" (sinkretisme) yang melanggar ajaran agama yang diyakini suci dan absolut oleh masing-masing pemeluknya, maka perlu ditegaskan bahwa konsep kerukunan dimaksud tidak menyangkut aspek iman (kepercayaan) dan ibadah (ritual), yang diatur secara khusus dalam masing-masing agama, melainkan menyangkut aspek hubungan sosial-kemanusiaan. Jadi tidak boleh terjadi kesepakatan untuk mencampurkan iman dan mencampurkan ibadah, di antara satu agama dengan agama lainnya.

Beberapa faktor pemicu yang dapat menimbulkan konflik antar agama yang patut diwaspadai adalah: menghakimi agama lain dalam derajad keabsahan teologis di bawah agamanya sendiri; konsep kebenaran dan kebaikan yang berakar dari ideologi politik atau wahyu Tuhan dipakai sebagai alasan pembenaran atas penindasan kemanusiaan; klaim kebenaran (truth claim) dan watak misioner setiap agama. Karena itu perlu pengkajian ulang terhadap konsep kerukunan antar umat beragama yang selama ini diterapkan pemerintah. Ia tidak lagi hanya sebagai bungkus formal dari kenyataan pluralitas agama di Indonesia, tetapi harus menjadi motivator bagi terbentuknya kesadaran beragama dan berteologi di Indonesia. ${ }^{5}$ Tujuannya adalah agar umat beragama memperoleh pemahaman dan wawasan yang luas dan cerah tentang kerukunan hidup umat beragama sehingga tumbuh dan berkembang penghayatan dan penyikapan yang positif untuk hidup rukun sesama umat beragama. Selanjutnya diharapkan muncul dan berkembang pula kegiatan dan kerjasama konkrit dalam rangka kerukunan hidup umat beragama.

\section{$\underline{\text { Dialog Antaragama }}$}

Secara resmi semangat dialog kerukunan beragama dirintis oleh Menteri Agama RI, yaitu H.A. Mukti Ali yang menjabat menteri pada tahun 1971-1978. Sebagai seorang pakar yang mempelajari Perbandingan Agama di Pakistan, Mukti Ali mencanangkan dialog sebagai bagian kebijakannya pada tahun 1972. Rintisan ini tidaklah mudah karena banyak yang menolak, tetapi tidak dapat disangkal bahwa usaha Menteri Agama kala itu disambut tokoh-tokoh agama dan sudah meletakkan dasar yang

4 Lih. Kompilasi Peraturan Perundang-undangan Kerukunan hidup Umat Beragama, Departemen Agama RI, Edisi Keenam (Jakarta, 1997/1998), 6

${ }^{5}$ Dadang Kahmad, Sosiologi Agama (Bandung: PT Remaja Rosdakarya, 2006), 
baik bagi usaha kerukunan antar umat beragama di Indonesia. Namun usaha itu agak tidak mulus di bawah penggantinya Alamsyah Ratu Prawiranegara. Usaha itu agak terganggu dengan dikeluarkannya dua Keputusan Menteri Agama: Kepmenag no.70/1978 tentang "Pedoman Penyiaran Agama" dan Kepmenag no. 78/1978 tentang "Bantuan Luar Negeri kepada Lembaga Keagamaan di Indonesia.” Kedua Kepmenag yang agak membatasi agama Kristen ini kemudian diperbaharui dalam: Kepmenag \& Mendagri no.1/ 1979 tentang "Tatacara Pelaksanaan Penyiaran Agama dan Bantuan Luar Negeri."

Sekalipun demikian dua tahun kemudian diterbitkan Kepmenag no.35/1980 tentang "'Wadah Musyawarah Antar Umat Beragama," dan sejak itu berbagai pertemuan antar umat beragama diadakan lebih sering. H.A. Mukti Ali menyebut "Dialog antar-umat beragama adalah pertemuan hati dan pikiran antara pelbagai macam agama merupakan komunikasi antara dua atau lebih orang yang beragama dalam tingkatan agamis. Dialog merupakan jalan bersama menuju ke arah kebenaran." Mukti Ali menyebut bahwa ada beberapa bentuk dialog yang bisa ditempuh, sebagai berikut.

Pertama, Dialog Kehidupan, yang ditunjukkan melalui kehidupan keseharian yang bisa dilihat oleh pemeluk agama lain.

Kedua, Dialog Kerja Sosial, melalui kerjasama dalam berbagai program kerja/aksi sosial demi kesejahteraan rakyat banyak.

Ketiga, Dialog Antar-Monastik, melalui komunikasi pengamalan agama, saling berkunjung atau belajar di asrama sekolah agama yang lain.

Keempat, Dialog untuk Doa Bersama, melalui pertemuan doa bersama di mana masing-masing pemeluk agama berdoa sesuai keyakinan masing-masing.

Kelima, Dialog Diskusi Teologis, melalui pertemuan/seminar antar para tokoh agama membicarakan beberapa aspek dari agama masingmasing.

Dialog antar umat beragama sangat diperlukan dalam konteks Indonesia yang bersifat plural untuk meminimalisir konflik agama-agama maupun antar pemeluk seagama. Dalam dialog antar agama, maka ada kebebasan hak setiap orang untuk mengamalkan keyakinannya dan menyampaikannya kepada orang lain. Dialog antar agama adalah pertemuan hati dan pikiran antar pemeluk berbagai agama yang bertujuan mencapai kebenaran dan kerjasama dalam masalah-masalah yang dihadapi bersama.

Menurut Ignas Kleden, dialog antar agama tampaknya hanya bisa dimulai dengan adanya keterbukaan suatu agama terhadap agama lainnya. Keterbukaan ini bisa dilihat dari beberapa sisi. Pertama, segi-segi mana 
dari suatu agama yang memungkinkannya terbuka terhadap agama yang lain, pada tingkat mana keterbukaan itu dapat ditolelir, dan juga dalam modus yang bagaimana keterbukaan itu dapat dilaksanakan. Kedua, bagaimana agama menjadi jalan dan sebab seseorang atau sekelompok orang terbuka kepada kelompok orang yang beragama lain. ${ }^{6}$

Wawasan inklusif adalah suatu pola pikir berciri non-diskriminatif, yang memberikan kerangka di dalam mana semua kelompok dalam masyarakat tanpa memandang suku, agama, dan golongan dapat hidup bersama, bekerja bersama untuk membangun masa depan bersama yang lebih baik, dengan tetap berpijak pada visi teologis yang diyakini setiap orang. Dengan demikian pemikiran inklusif adalah pemikiran yang mengakomodasi, memberi tempat, menghargai kelompok lain dan sebab itu jauh dari sikap yang meniadakan kelompok lain atau sikap membenarkan. Pengembangan sikap inklusif sama sekali tidak berarti dan tidak boleh memperlemah iman dan atau mengingkari nilai eksklusif dan spesifik yang ada dalam setiap agama. Pengembangan sikap inklusif di kalangan umat Kristen perlu dilakukan secara terarah, berkesinambungan dan mencakup seluruh lapisan umat. Dalam konteks ini problem dan kendala yang amat jelas dihadapi adalah: keragaman denominasi, keragaman latar belakang pendidikan, persepsi teologis yang tidak sama, pola pembinaan umat beragama yang belum merata, dan persepsi tentang kerukunan.

\section{Kerjasama Antar Lembaga Agama}

Pada tanggal 22-24 Agustus 2006, para tokoh agama se-Indonesia berkumpul pada Kongres I Pemuka Agama yang diprakarsai oleh Departemen Agama guna mendiskusikan berbagai persoalan umat beragama. Kongres dibuka oleh Menko Kesra saat itu, Aburizal Bakri, di Hotel Acacia, Jakarta, dan diikuti 225 orang pemuka agama seluruh Indonesia, terdiri dari: Utusan Provinsi, masing-masing 6 orang berupa wakil dari majelis-majelis Agama tingkat pusat dan propinsi (MUI, PGI, KWI, PHDI, WALUBI, MATAKIN) atau Ormas Keagamaan dan Kepala Kanwil Agama setempat.

Tiga Agenda Kongres yang bertema "Membangun Kerjasama, Mengatasi Berbagai Problema, Meningkatkan Kontribusi umat Bagi Kemajuan Bangsa," antara lain membahas 3 agenda: Pertama, merancang keberagaman umat ke depan supaya beragama secara dewasa; Kedua, Pancasila sebagai etika bersama dalam kehidupan berbangsa dan bernegara;

\footnotetext{
${ }^{6}$ Kahmad, Sosiologi Agama..., 178
} 
Ketiga, merumuskan aksi bersama umat beragama menghadapi tantangan global dan tantangan internal bangsa.

Keinginan untuk menyelenggarakan kongres ini didasarkan pada pemikiran, bahwa umat beragama dewasa ini tengah dihadapkan pada berbagai persoalan yang menyangkut isu-isu global yang turut mempengaruhi sikap dan prilaku keberagamaan masyarakat di tingkat lokal. Pengaruh tersebut pada tingkat tertentu dapat dilihat sebagai problem kultural dan sosial, persoalan hak asasi manusia (HAM), harmonisasi sosial, demokrasi beragama dan tidak kalah pentingnya adalah persoalanpersoalan yang menyangkut absolutisme dan relativisme pada tingkat kesadaran teologis umat beragama yang sedikitnya turut mempengaruhi kebijakan-kebijakan pemerintah dalam melakukan pelayanan terhadap para penganut agama-agama.

Para tokoh berbagai agama yang tergabung dalam Kongres I ini menyerukan pentingnya revitalisasi peran ideologi Pancasila dalam membina kerukunan hidup bermasyarakat karena berbagai konflik suku, agama, ras, dan antar-golongan (SARA) yang terjadi selama ini ditengarai sebagai dampak dari merosotnya penghayatan nilai-nilai Pancasila dalam masyarakat. Saat menyampaikan sambutan pada penutupan kongres, Menteri Agama saat itu, Maftuh Basyuni menegaskan kembali posisi Pancasila sebagai dasar negara. "Pancasila harus menjadi acuan dari seluruh sistem hukum dan sistem politik negara."

Kongres ini menghasilkan tiga rekomendasi, yaitu: Pertama, negara diminta menjamin kebebasan beribadah dan mendorong peningkatan penghayatan serta pengamalan nilai agama yang dianut oleh masing-masing pemeluknya. Kedua, perlu ada rencana aksi sebagai tindak lanjut kongres tokoh agama. Ketiga, memberdayakan forum kerukunan umat beragama (FKUB) dalam meningkatkan kesejahteraan dan kerukunan umat beragama.

Kerjasama antar lembaga-lembaga keagamaan sangat diperlukan dalam konteks saling menghargai dan saling melengkapi, demi kemajuan bersama. Ada banyak kegiatan yang sebenarnya dapat dilakukan bersama antara lembaga-lembaga keagamaan demi meningkatkan suasana kehidupan keagamaan yang kondusif bagi pembinaan kerukunan intern dan antarumat beragama di Indonesia, antara lain: Melakukan forum dialog dan temu ilmiah, Membuka sekretariat bersama antar umat beragama di seluruh propinsi, Melakukan silaturahmi/safari kerukunan umat beragama baik nasional maupun di tingkat daerah/regional, Membentuk forum komunikasi kerukunan antar umat beragama di tingkat propinsi, kabupaten/kota dan kecamatan, Melanjutkan pembentukan jaringan komunikasi kerukunan antar umat beragama dan meningkatkan peran jaringan kerjasama antar 
umat beragama, Melakukan rekonsiliasi tokoh-tokoh agama di daerah pasca konflik, Menyediakan data kerukunan umat beragama, Pembinaan umat beragama di daerah pasca konflik, Sosialisasi wawasan multikultural bagi umat beragama, Pengembangan wawasan multikultural bagi guru-guru agama, Meningkatkan potensi kerukunan hidup umat beragama melalui pemanfaatan budaya setempat dan partisipasi masyarakat, Mendorong tumbuh kembangnya wadah-wadah kerukunan sebagai penggerak pembangunan, Melakukan silaturahmi antara pemuda agama dan cendekiawan agama serta tokoh agama, Menyelenggarakan lomba kegiatan keagamaan bernuansa kerukunan di daerah potensi konflik, Meningkatkan kualitas tenaga penyuluh kerukunan umat beragama.

\section{MASA DEPAN HARMONISASI UMAT BERAGAMA DI INDONESIA}

Masyarakat majemuk (plural) dapat dipahami sebagai masyarakat yang terdiri dari berbagai kelompok dan strata sosial, ekonomi, suku, bahasa, budaya dan agama. Di dalam masyarakat plural, setiap orang dapat bergabung dengan kelompok yang ada, tanpa adanya rintangan-rintangan yang sistemik yang mengakibatkan terhalangnya hak untuk berkelompok atau bergabung dengan kelompok tertentu.

Pluralitas baru bermakna positif bila ada interaksi dan relasi saling percaya antara sesama (social-trust). Hal itu merupakan prasyarat untuk terciptanya masyarakat yang beradab dan bermartabat, yaitu masyarakat yang memiliki moral, akhlak, etika, budi luhur, santun, sabar dan arif, menghormati hak asasi, menghormati diri sendiri dan orang lain, bangsa sendiri dan bangsa lain, suku dan kelompok sendiri dan suku serta kelompok lain. Dengan begitu upaya untuk mencapai kualitas hidup yang optimal untuk menjadi lebih sejahtera, berkeadilan dan berkemakmuran, niscaya akan membawa masyarakat itu dapat duduk sama rendah dan tegak sama tinggi dengan bangsa-bangsa lain di dunia. Untuk maksud tersebut diperlukan infra struktur harmonisasi sosial dalam kehidupan bersama. Menghormati pluralitas harus sejalan dengan menghormati peradaban dan martabat. Tidak ada artinya pluralitas kalau yang dipertahankan adalah budaya primitif, keterbelakangan dan hanya asal berbeda dengan alasan kemurnian penghormatan budaya lokal atau hak asasi manusia tanpa mempertimbangkan hak manusia lainnya dalam sistem kehidupan bersama beradab dan bermartabat. 
Diperlukan pula kesadaran mendalam ke arah revitalisasi dan reaktualisasi pemberdayaan agama sebagai standard moral bagi umat beragama, bukan sekedar simbol identitas tanpa makna substansial. Di sisi lain, dunia saat ini tengah membangun peradaban multikulturalis yang menerima realitas pluralitas agama dan budaya sebagai kesadaran global untuk menghadapi problematika universal yang tidak bisa ditanggulangi secara komunal parsial. Konstruksi ini meniscayakan harmonisasi, sinergisitas, dan integralitas antar umat beragama. Elit agama harus mentransformasikan paradigma ini kepada masing-masing komunitasnya, serta tidak dinodai semangat penyebaran agama yang agresif dan ekspansif.

Para tokoh nasional khususnya tokoh agama dituntut mampu memberi jalan keluar bagi persoalan umat beragama. Semua upaya itu akan berarti jika para elit politik maupun elit agama memberi contoh sikap hidup yang harmonis. Keteladanan para pemimpin akan memberi pengaruh yang berarti bagi masyarakat di tingkat akar rumput. Sebab, konflik yang selama ini terjadi di antara warga daerah sebagiannya lebih banyak dipicu oleh perilaku elit di tingkat pusat. Mereka yang menjadi korban hanyalah tumbal dari provokasi elit.

Untuk masa depan harmonisasi umat beragama di Indonesia perlu dikembangkan pemahaman pluralisme bangsa sebagai upaya untuk membangun tidak saja kesadaran normatif teologis, tetapi juga kesadaran sosial, di mana kita hidup di tengah masyarakat yang plural dari segi agama, budaya, etnis, dan berbagai keragaman sosial lainnya. Karena itu, pluralisme bukanlah konsep teologis semata, melainkan juga konsep sosiologis. Franz Magnis Suseno memberikan catatan yang patut dikaji oleh masyarakat agama-agama, bahwa tantangan agama-agama di masa mendatang adalah merebaknya konflik, baik antar-umat agama maupun inter-umat agama itu sendiri. Di sinilah arti penting pluralisme sebagai jembatan untuk meminimalisasi dan mengakhiri konflik tersebut. Maka, kita perlu mengubah kerangka berpikir (mindset) yang masih keliru. Kita perlu belajar untuk duduk bersama, saling mendengar dan bertukar pikiran, baik dengan sesama muslim maupun non-muslim.

Upaya untuk mencairkan kebekuan wacana pluralisme juga bisa dipercepat dengan jalan mengintensifkan pendidikan pluralisme dan multikulturalisme di sekolah-sekolah. Lembaga pendidikan adalah media yang paling tepat untuk mereparasi mindset seseorang. Untuk itu, diperlukan adanya upaya-upaya untuk mengubah paradigma pendidikan yang eksklusif menuju paradigma pendidikan agama yang toleran dan inklusif. Model pengajaran agama yang hanya menekankan kebenaran agamanya sendiri mau tidak mau harus 'dibongkar ulang.' Sebab cara 
pemahaman teologi yang ekslusif dan intoleran pada gilirannya akan dapat merusak harmonisasi agama-agama dan menghilangkan sikap untuk saling menghargai kebenaran dari agama lain. Pluralisme adalah simbol bagi suksesnya kehidupan masyarakat majemuk.

Menganggap agama yang satu lebih baik dari agama lain adalah ofensif, berpandangan sempit. Saat ini masih belum banyak dijumpai bukubuku agama mengenai pluralisme. Penulisan ulang buku agama dan memasukkannya dalam kurikulum berbasis pluralisme harus sering dilakukan. Untuk selanjutnya, dapat dipakai buku ajar dan menjadi panduan guru-guru.

Untuk menghadapi realitas dunia yang plural ini, umat beragama dituntut untuk mampu menempatkan diri dan memahami konteks pluralisme yang dilandasi semangat saling menghormati dan menghargai keberadaan umat beragama lain. Karena itu, ada beberapa pengertian pluralisme yang perlu dipahami oleh masing-masing umat beragama. Pertama, pluralisme tidak semata-mata menunjuk pada kenyataan tentang adanya kemajemukan. Namun, yang dimaksud adalah "keterlibatan aktif" terhadap kenyataan kemajemukan tersebut. Pengertian pluralisme agama adalah bahwa tiap pemeluk agama dituntut bukan saja untuk mengakui keberadaan dan hak agama lain, tapi juga terlibat dalam usaha memahami perbedaan dan persamaan guna tercapainya kerukunan dalam kebinekaan. Kedua, pluralisme agama bukanlah sinkretisme, yakni menciptakan suatu agama baru dengan memadukan unsur tertentu atau sebagian komponen ajaran dari beberapa agama untuk dijadikan bagian integral dari agama baru tersebut.

Pluralisme bukan hanya beragam atau majemuk, pluralisme lebih dari sekadar majemuk atau beragam dengan ikatan aktif kepada kemajemukan tadi. Pluralisme lebih dari sekadar toleransi dengan usaha yang aktif untuk memahami orang lain. Meskipun toleransi sudah pasti merupakan sebuah langkah ke depan dari ketidaktoleransian, toleransi tidak mengharuskan kita untuk mengetahui segala hal tentang orang lain. Toleransi dapat menciptakan iklim untuk menahan diri, tetapi tidak untuk memahami. Toleransi saja tidak banyak menjembatani jurang stereotip dan kekhawatiran yang bisa jadi justru mendominasi gambaran bersama mengenai orang lain. Sebuah dasar yang terlalu rapuh untuk sebuah masyarakat yang kompleks secara religius. Pluralisme harus berkembang melebihi toleransi untuk mencapai pemahaman yang konstruktif. Namun, tidak sekadar berhenti pada wacana pentingnya pluralisme dan multikulturalisme, tetapi lebih diwujudkan pada tataran praksis melalui jalur pendidikan dan pelatihan-pelatihan bersama dengan melibatkan 
berbagai komunitas lintas agama dan etnis untuk saling mengenal, memahami, dan membangun sikap saling menghargai berdasarkan pengakuan atas persamaan, kesetaraan, dan keadilan.

\section{PENUTUP}

Kehadiran Perda syariat, pada satu sisi merefleksikan kegagalan pemerintah dalam mengimplementasi hukum di Indonesia. Kegagalan ini berdampak pada sisi lain, di mana kemudian banyak orang merasa berhak untuk membuat atau mencari aturan alternatif karena menunjuk ketidakmampuan hukum dalam mengatasi berbagai persoalan.

Untuk itu saat ini perlu dikaji ulang konsep kerukunan antar umat beragama tidak hanya sebagai bungkus formal semata, tetapi menjadi pemicu dan pemacu terbentuknya kesadaran beragama dan berteologi di Indonesia. Tujuannya agar umat beragama memperoleh pemahaman dan wawasan yang luas dan cerah tentang kerukunan hidup umat beragama sehingga tumbuh dan berkembang penghayatan dan penyikapan yang positif untuk hidup rukun sesama umat beragama. 